\title{
DAMPAK KEBIJAKAN RESTRUKTURISASI KREDIT DI MASA PANDEMI COVID- 19 TERHADAP KINERJA PERBANKAN DI INDONESIA
}

Teguh Rimbawan*

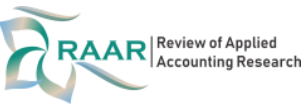

Affiliation:

Accounting Department, Politeknik Muhammadiyah Tegal, Indonesia

*Correspondence: rimbawanteguh@gmail.com

Article Process:

Submitted:

December 21, 2021

Reviewed:

January 24, 2022

Revised:

February 5, 2022

Accepted:

February 10, 2022

Published:

February 15, 2022

Citation:

Rimbawan, Teguh. (2022).

Dampak Kebijakan

Restrukturisasi Kredit Di Masa

Pandemi Covid-19 Terhadap

Kinerja Perbankan Di Indonesia.

RAAR: Review of Applied

Accounting Research, 1(2), 206218.

Office Address:

Jl. K.H. Ahmad Dahlan,

Dukuhwaluh, Kec.

Kembaran, Kabupaten

Banyumas, Jawa Tengah

53182

e-ISSN : 2807-8969

\begin{abstract}
ABSTRAK
Penelitian ini bertujuan untuk mengetahui dampak penerapan kebijakan restrukturisasi kredit di masa pandemi COVID-19 terhadap kinerja keuangan perbankan di Indonesia. Restrukturisasi kredit di masa pendemi COVID-19 merupakan pelaksanaan Peraturan Otoritas Jasa Keuangan Republik Indonesia Nomor 11/POJK.03/2020 tentang Stimulus Perekonomian Nasional Sebagai Kebijakan Countercyclical Dampak Penyebaran COVID-19 (Otoritas Jasa Keuangan, 2020). Populasi penelitian yaitu seluruh bank terdaftar di Otoritas Jasa Keuangan (OJK). Pemilihan sample menggunakan metode purposive sampling untuk laporan keuangan bank yang diterbitkan tahun 2019 dan tahun 2020. Penelitian ini menggunakan Uji Wilcoxon untuk mengukur seberapa besar perbedaan kinerja keuangan perbankan sebelum dan sesudah diumumkannya pemberlakuan POJK No.11 tahun 2020. Kinerja keuangan bank diukur menggunakan Tingkat Kesehatan Bank dengan pendekatan Risiko (Riskbased Bank Rating/RBBR) yaitu Good Corporate Governance (GCG), Profil risiko (risk profile) diukur menggunakan rasio Non Performing Loan/Financing (NPL/NPF) dan Loan/Financing to Deposit Ratio (LDR/FDR), Rentabilitas (earnings) diukur menggunkan rasio Return of Assets (ROA), serta Permodalan (capital) menggunakan rasio Capital Addequacy Ratio (CAR). Hasil penelitian dapat disimpulkan bahwa kinerja keuangan perbankan berdasar NPL/NPF tidak ada perbedaan sebelum dan sesudah penerapan kebijakan restrukturisasi kredit di masa pandemi COVID-19, sedangkan untuk LDR/FDR, ROA, dan CAR ada perbedaan.
\end{abstract}

Kata kunci: POJK, NPL/NPF, LDR.FDR, ROA, CAR

\section{ABSTRACT}

This study aims to determine the impact of implementing credit restructuring policies during the COVID-19 pandemic on banking financial performance in Indonesia. Credit restructuring policies during the COVID-19 pandemic as the implementation of the Financial Services Authority Regulation of the Republic of Indonesia Number 11/POJK.03/2020 concerning National Economic Stimulus as a Countercyclical Policy for the Impact of the Spread of COVID-19 (Otoritas Jasa Keuangan, 2020). The research population is all banks registered with the Financial Services Authority (OJK). The sample selection used purposive sampling method for bank financial statements published in 2019 and 2020. This study uses the Wilcoxon Test to measure 
how big the difference is in banking financial performance, before and after the announcement of the implementation of POJK No. 11 of 2020. Bank financial performance is measured using the level Bank Health with a Risk-based Bank Rating (RBBR) approach, namely Good Corporate Governance (GCG), Risk profile is measured using the ratio of Non Performing Loan/Financing (NPL/NPF) and Loan/Financing to Deposit Ratio (LDR)/FDR), Profitability (earnings) is measured using the ratio of Return of Assets (ROA), and Capital (capital) using the ratio of Capital Addequacy Ratio (CAR). The results of the study can be concluded that there is no difference in banking financial performance in NPL/NPF before and after the announcement of implementing credit restructuring policies during the COVID-19 pandemic, while for $L D R / F D R, R O A$, and CAR there are differences.

Keywords: POJK, NPL/NPF, LDR.FDR, ROA, CAR

\section{PENDAHULUAN}

Pandemi Corona Virus Disease 2019 (COVID-19) yang melanda seluruh belahan dunia membuat perekonomian tiba-tiba terhenti. Perekonomian yang terhenti berpotensi menimbulkan gelombang krisis ekonomi, yang pada gilirannya akan memicu krisis multidimensi. Ini dikuatkan dalam penelitian (Junaedi \& Salistia, 2020) yang menyatakan bahwa pendemi COVID-19 berdampak negatif terhadap pertumbuhan ekonomi. Dalam upaya menangani krisis yang mungkin akan terus berlanjut, maka Pemerintah Indonesia memberi perhatian khusus terhadap industri perbankan. Berdasar UU No 10. Tahun 1998 disebutkan bahwa bank merupakan lembaga intermediasi, oleh karena itu bank dianggap memiliki peran yang sangat penting dan strategis dalam upaya menopang pembangunan ekonomi nasional Indonesia (Pemerintah Republik Indonesia, 1998).

Salah satu kebijakan pemerintah dimasa pandemi COVID-19 yaitu dengan memberi perhatian terhadap kinerja dan kapasitas debitur dalam memenuhi kewajiban pembayaran kredit maupun pembiayaan mereka. Dimana penurunan kinerja dan kapasitas debitur akan meningkatkan risiko kredit yang berpotensi mengganggu kinerja perbankan dan stabilitas sistem keuangan, sehingga pada gilirannya dapat mempengaruhi pertumbuhan ekonomi. Tindakan ini diambil pemerintah untuk mencegah timbulnya resiko sistemik yang bermula dari tergoncangnya industri perbankan dikarenakan oleh terganggunya kinerja keuangan mereka. Bukti empiris atas hubungan keadaan diatas telah diteliti oleh Davis, dia menyatakan bahwa setiap sistem keuangan memiliki resiko sistemik yang berkaitan erat dengan kekayaan dan kesehatan lembaga keuangan (Davis, 2003).

Terkait hal tersebut, Pemerintah Indonesia pada tanggal 13 Maret 2020 melalui Otoritas Jasa Keuangan (OJK) mengeluarkan Peraturan Otoritas Jasa Keuangan Republik Indonesia Nomor 11/POJK.03/2020 tentang Stimulus Perekonomian Nasional Sebagai Kebijakan Countercyclical Dampak Penyebaran COVID-19 (Otoritas Jasa Keuangan, 2020). Tujuan kebijakan ini yaitu untuk mendorong optimalisasi kinerja perbankan khususnya fungsi intermediasi, menjaga stabilitas sistem keuangan, dan mendukung pertumbuhan ekonomi. Berdasar stimulus diatas, bank dapat melakukan restrukturisasi kredit sesuai dengan assessment masing-masing bank.

Studi tentang dampak kebijakan dan regulasi pemerintah terhadap permasalahan kredit perbankan sangat penting untuk dilakukan, dengan tujuan untuk memperkuat pengetahuan para pemangku kepentingan dalam bersikap dan bertindak, serta meminimalisir konsekuensi negatif yang mungkin akan muncul. Penelitian dengan tema dampak 
penerapan kebijakan restrukturisasi kredit di masa pandemi COVID-19 terhadap kinerja keuangan perbankan di Indonesia, sebagai pelaksanaan Peraturan Otoritas Jasa Keuangan Republik Indonesia Nomor 11/POJK.03/2020 tentang Stimulus Perekonomian Nasional Sebagai Kebijakan Countercyclical Dampak Penyebaran COVID-19 (POJK No.11 tahun 2020) belum banyak dilakukan. Oleh karena itu, perlu dilakukan penelitian untuk mengetahui dampak penerapan kebijakan stimulus ini terhadap kinerja perbankan yang sedang menghadapi meningkatnya resiko kredit dimasa pandemi COVID-19. Penelitian ini bermanfaat bagi para pemangku kepentingan sebagai salah satu bahan pertimbangan kebijakan lanjutan dalam penanganan dampak pandemi COVID-19 yang belum dapat dipastikan kapan akan berakhir.

\section{TINJAUAN PUSTAKA}

Indonesia adalah negara yang menganut sistem perbankan ganda (dual banking system). Sistem ini mulai berlaku semenjak amandemen Undang-Undang No. 7 Tahun 1992 tentang Perbankan menjadi Undang-Undang No. 10 Tahun 1998. Menurut OJK dalam Statistik Perbankan Indonesia yang diterbitkan bulan Januari 2021 tercatat terdapat 109 Bank Umum, dengan rincian 95 Bank Umum Konvensional dengan 19 diantaranya memiliki Unit Usaha Syariah, dan 14 Bank Umum Syariah (Otoritas Jasa Keuangan, 2021).

Menurut UU Nomor 10 tahun 1998 tentang Perubahan Atas Undang-Undang Nomor 7 Tahun 1992 Tentang Perbankan, Bank Konvensional yaitu badan usaha (Bank) yang menghimpun dana dari masyarakat dalam bentuk simpanan dan menyalurkannya kepada masyarakat dalam bentuk kredit dan atau bentuk-bentuk lainnya dalam rangka meningkatkan taraf hidup rakyat banyak, yang melaksanakan kegiatan usaha secara konvensional yang dalam kegiatannya memberikan jasa dalam lalu lintas pembayaran. Masih menurut undang-undang yang sama Bank Syariah yaitu badan usaha (Bank) yang menghimpun dana dari masyarakat dalam bentuk simpanan dan menyalurkannya kepada masyarakat dalam bentuk kredit dan atau bentuk-bentuk lainnya dalam rangka meningkatkan taraf hidup rakyat banyak, yang melaksanakan kegiatan usaha berdasarkan prinsip syariah yang dalam kegiatannya memberikan jasa dalam lalu lintas pembayaran.

Sedangkan pengertian prinsip syariah yaitu aturan perjanjian berdasarkan hukum Islam antara bank dan pihak lain untuk penyimpanan dana dan atau pembiayaan kegiatan usaha, atau kegiatan lainnya yang dinyatakan sesuai dengan prinsip Syariah. Antara lain pembiayaan berdasarkan prinsip bagi hasil (mudharabah), pembiayaan berdasarkan prinsip penyertaan modal (musharakah), prinsip jual beli barang dengan memperoleh keuntungan (murabahah), atau pembiayaan barang modal berdasarkan prinsip sewa murni tanpa pilihan (ijarah), atau dengan adanya pilihan pemindahan kepemilikan atas barang yang disewa dari pihak bank oleh pihak lain (ijarah wa iqtina).

Kinerja keuangan bank merupakan gambaran kondisi keuangn bank pada suatu periode tertentu baik menyangkut aspek penghimpunan dana maupun penyaluran dana (fungsi intermediasi). Kinerja keuangan Bank diukur menggunakan analisis rasio, yaitu analisis

RAAR yang digunakan untuk mengetahui hubungan pos-pos yang ada dalam suatu laporan keuangan atau pos-pos antara laporan keuangan neraca dan laporan laba rugi (Kasmir, Vol.2 No.1 2018). Kinerja keuangan Bank merupakan salah satu faktor yang termasuk ke dalam penilaian kesehatan bank. Terkait hal ini Otoritas Jasa Keuangan menerbitkan Peraturan Otoritas Jasa Keuangan Nomor 4/POJK.03/2016 tentang Penilaian Tingkat Kesehatan 
Bank Umum (Otoritas Jasa Keuangan, 2017) dan petunjuk pelaksanaannya melalui Peraturan Bank Indonesia Nomor 13/1/PBI/2011 Tentang Penilaian Tingkat Kesehatan Bank Umum yang berlaku 27 Desember 2016 (Bank Indonesia, 2011). Peraturan ini mewajibkan Bank Umum untuk melakukan penilaian sendiri (self assessment) Tingkat Kesehatan Bank dengan menggunakan pendekatan Risiko (Risk-based Bank Rating/RBBR) baik secara individual maupun secara konsolidasi, yaitu dengan melakukan analisa terhadap faktor-faktor penilaian tingkat Kesehatan Bank yang terdiri dari: Profil risiko (risk profile), Good Corporate Governance (GCG), Rentabilitas (earnings), dan Permodalan (capital). Dari keempat faktor tersebut, GCG merupakan analisi kualitatif tentang penerapan praktek baik dalam tata kelola pada bank yang bersangkutan, sedangkan faktor profil resiko, rentabilitas, dan permodalan bersumber dari data yang diolah dari laporan keuangan.

Profil resiko merupakan penilaian terhadap resiko inheren dan kualitas penerapan manajemen resiko dalam operasional bank. Terdapat dua jenis resiko yaitu:

1. Resiko Kredit

Resiko Kredit adalah resiko tidak kembalinya pinjaman sesuai dengan kontrak. Resiko Kredit dapat ditentukan dengan menghitung rasio Non Performing Loan/Financing dengan rumus sebagai berikut:

$$
N P L=\frac{\text { Kredit Bermasalah }}{\text { Total Kredit }} \times 100 \%
$$

2. Resiko Liquiditas

Menurut Rivai, dkk (2007:386), likuiditas adalah kemampuan manajemen menyediakan dana yang cukup bagi bank dalam memenuhi kewajibannya setiap saat. Sedangkan resiko likuiditas terjadi karena adanya penarikan dana secara serentak yang dapat mengakibatkan kebangkrutan bank. Resiko Likuiditas dapat ditentukan dengan menghitung Loan/Financing to Deposit Ratio dengan rumus sebagai berikut:

$$
L D R=\frac{\text { Total Kredit }}{\text { Dana Pihak Ketiga }} \times 100 \%
$$

3. Profil earnings adalah suatu penilaian kesehatan bank dari sisi rentabilitas, sehingga sering disebut rasio rentabilitas. Indikator profil earnings antara lain Return of Assets $(R O A)$, adalah analisa yang membandingkan antara laba kotor dengan rata-rata total asset. Dengan rumus sebagai berikut:

$$
R O A=\frac{\text { Laba Sebelum Pajak }}{\text { Rata-rata } \text { Total } \text { Asset }} \times 100 \%
$$

4. Profil Capital adalah suatu penilaian kesehatan bank dari sisi capital atau permodalan, sehingga sering disebut Capital Addecuacy Ratio (CAR). Indikator profil capital yaitu Capital Addequacy Ratio yang dirumuskan sebagai berikut:

$$
\begin{aligned}
& \text { CAR }=\frac{\text { Modal }}{\text { ATMR }} \times 100 \% \\
& \text { Keterangan: } \\
& \text { Aset Tertimbang Menurut Risiko (ATMR) } \\
& \text { ATMR }=12,5 \times \text { Beban Modal Risiko Operasional }
\end{aligned}
$$

5. Beban Modal Risiko Operasional adalah rata-rata dari penjumlahan pendapatan bruto (gross income) tahunan (Januari-Desember) yang positif pada 3 (tiga) tahun terakhir Vol.2 No.1 dikali 15\% (lima belas persen). 
$\mathrm{K}_{\mathrm{PID}}=\frac{\left[\sum\left(\mathrm{GI}_{1 \ldots n} \times \alpha\right)\right]}{n}$

Keterangan:

$K_{\text {PID }}$ : beban modal Risiko Operasional menggunakan Pendekatan Indikator Dasar GI : pendapatan bruto positif tahunan dalam tiga tahun terakhir

$\mathrm{n} \quad$ : jumlah tahun di mana pendapatan bruto positif

$\alpha: 15 \%$

Restrukturisasi menurut (Hariyani, 2010) dalam arti luas mencakup perubahan struktur organisasi, manajeman, operasional sistem dan prosedur, keuangan, asset, hutang, pemegang saham, legal dan sebagainya. Sedangkan menurut (Veithzal, Rivai \& Idroes, 2007), restructuring merupakan upaya penyelamatan dengan melakukan perubahan syarat-syarat perjanjian kredit berupa pemberian tambahan kredit atau melakukan konversi atas seluruh atau sebagian dari kredit menjadi equity perusahaan dan equity bank yang dilakukan dengan atau tanpa rescheduling dan reconditioning.

Sedangkan (Firdaus, Rachmat; Ariyanti, 2003) mengemukakan pengertian bahwa: restrukturisasi kredit adalah upaya yang dilakukan dalam kegiatan usahanya perkreditan agar debitur dapat memenuhi kewajibannya. Berdasar beberapa definisi diatas maka dapat didefinisikan bahwa Restrukturisasi Kredit adalah upaya perbaikan yang dilakukan bank dalam kegiatan perkreditan terhadap debitur yang mengalami kesulitan memenuhi kewajibannya, yang dilakukan antara lain dengan melakukan perubahan syarat-syarat perjanjian kredit berupa pemberian tambahan kredit atau melakukan konversi atas seluruh atau sebagian dari kredit menjadi equity perusahaan dan equity bank yang dilakukan dengan atau tanpa rescheduling dan reconditioning Sementara itu OJK secara teknis mendefinisikan restrukturisasi kredit sebagai berikut:

1. Restrukturisasi adalah keringanan pembayaran cicilan pinjaman di bank/Leasing.

2. Restrukturisasi bukan penghapusan hutang, tapi memberikan keringanan untuk membayar cicilan hutang. Cicilan pinjaman tetap harus dibayar namun diberikan keringanan berdasarkan penilaian dan kesepakatan bersama antara nasabah dengan Bank/Leasing.

3. Bentuk-bentuk keringanan kredit/pembiayaan yang bisa diberikan Bank/Leasing, yaitu:

a. Penurunan suku bunga.

b. Perpanjangan jangka waktu.

c. Pengurangan tunggakan pokok.

d. Pengurangan tunggakan bunga.

e. Penambahan fasilitas kredit/pembiayaan.

f. Konversi kredit/pembiayaan menjadi Penyertaan Modal Sementara.

4. Pemberian keringanan ini diutamakan untuk usaha kecil yang terkena dampak COVID-19 dengan nilai pinjaman di bawah Rp 10 Milyar, terutama UMKM, pekerja harian, nelayan, ojek online dan usaha kecil lain yang sejak terkena dampak Covid-19 mengalami kesulitan membayar cicilan pinjaman. Pemberian keringanan ini untuk membantu masyarakat yang kesulitan membayar pinjaman, namun di sisi lain dapat tetap menjaga stabilitas keuangan. 
5. Bank/Leasing diberi kewenangan untuk melaksanakan assessment terkait penerapan restrukturisasi kredit nasabahnya. Bank/Leasing harus selektif dalam penerapan restrukturisasi kredit. Karena Bank/Leasing berpotensi mengalami kesulitan pemasukan akibat terkena dampak Covid-19 sementara Perusahaan Bank/Leasing tetap harus membayar bunga kepada para penabung/investor dan mengeluarkan biaya operasional (menggaji karyawan, biaya sewa, listrik, air, dan lain-lain) sementara tidak ada pendapatan dari nasabah.

Restrukturisasi kredit bertujuan untuk menjaga rasio Non Performing Loan (NPL) dan NPL Coverage dari suatu bank. Gerak perekonomian yang melambat akan menjadi penyebab meningkatnya kredit bermasalah (NPL). Tingkat NPL yang tinggi menjadi masalah serius karena mengganggu neraca bank, menekan pertumbuhan kredit, dan menunda pemulihan ekonomi (Aiyar et al., 2015); (Kalemli-Özcan et al., 2019). Rasio NPL yang tinggi telah menjadi perhatian Bank Indonesia dan OJK terutama paska krisis 2008-2012, dan pandemi COVID-19 yang berkepanjangan dapat menyebabkan munculnya kembali masalah NPL.

Kondisi perekonomian yang mempengaruhi iklim usaha menjadi salah satu faktor penyebab risiko kredit bermasalah, yang pada gilirannya akan menimbulkan wanpretasi debitur. Restrukturisasi Kredit menjadi alternatif baru dalam menurunkan NPL. Restrukturisasi Kredit merupakan upaya perbaikan yang dilakukan Bank dalam kegiatan perkreditan terhadap debitur yang mengalami kesulitan untuk memenuhi kewajibannya. Keuntungan restrukturisasi kredit bagi bank adalah dengan melamatkan usaha debitur yang direstrukturisasi maka nilai NPL Bank dapat berkurang serta CKPN yang seharusnya dianggarkan untuk potensi kredit bermasalah dapat terselamatkan dan dapat digunakan untuk pembiayaan lainnya (Sihotang \& Sari, 2019). Dari uraian diatas, maka dapat ditarik hipotesis terkait NPL/NPF sebelum dan sesudah penerapan kebijakan restrukturisasi kredit di masa pandemi COVID-19 yaitu sebagai berikut:

$\mathrm{Ho}_{1}$ : Tidak ada perbedaan rata-rata rasio NPL/NPF sebelum dan sesudah penerapan kebijakan restrukturisasi kredit di masa pandemi COVID-19

$\mathrm{Ha}_{1}$ : Ada perbedaan rata-rata rasio NPL/NPF sebelum dan sesudah penerapan kebijakan restrukturisasi kredit di masa pandemi COVID-19

Disamping itu, restrukturisasi kredit juga berpotensi memberikan dampak negatif terhadap cash flow bank dalam jangka pendek. Karena salah satu bentuk restrukturisasi kredit adalah penangguhan pembayaran bunga kredit atau pokok kredit hingga 1 (satu) tahun. Hal ini akan mempengaruhi kemampuan bank dalam menyediakan dana untuk membiayai kegiatannya (solvabilitas bank, rasio CAR).

$\mathrm{Ho}_{2}$ : Tidak ada perbedaan rata-rata rasio CAR sebelum dan sesudah penerapan kebijakan restrukturisasi kredit di masa pandemi COVID-19

$\mathrm{Ha}_{2}$ : Ada perbedaan rata-rata rasio CAR sebelum dan sesudah penerapan kebijakan restrukturisasi kredit di masa pandemi COVID-19

Restrukturisasi kredit juga mengakibatkan tenor kredit perbankan menjadi lebih panjang. Sehingga akan berimbas pada potensi penurunan kemampuan bank dalam menghasilkan laba (rentabilitas bank, rasio ROA). Adhinugroho dalam artikelnya menyatakan bahwa telah terjadi peningkatan restrukturisasi kredit yang signifikan antara sebelum dan sesudah COVID-19 yang dihadapi oleh perbankan di Indonesia (Adhinugroho, 2021). Sehingga diikuti dengan penurunan profitabilitas perbankan antara sebelum dan sesudah COVID-19.

RAAR Vol.2 No.1 
Hal ini menunjukkan bahwa peningkatan restrukturisasi kredit berdampak negatif terhadap profitabilitas perbankan. Dari uraian diatas, maka dapat ditarik hipotesis terkait profitabilitas perbankan yang diproxikan dengan ROA (Return on Assets) sebelum dan sesudah penerapan kebijakan restrukturisasi kredit di masa pandemi COVID-19 yaitu sebagai berikut:

$\mathrm{Ho}_{3}$ : Tidak ada perbedaan rata-rata rasio ROA sebelum dan sesudah penerapan kebijakan restrukturisasi kredit di masa pandemi COVID-19

$\mathrm{Ha}_{3}$ : Ada perbedaan rata-rata rasio ROA sebelum dan sesudah penerapan kebijakan restrukturisasi kredit di masa pandemi COVID-19

Keadaan ini juga akan menekan tingkat likuiditas bank (rasio LDR), dimana bank akan mengalami kesulitan pada saat harus membayarkan interest expense kepada kreditur (terutama Dana Pihak Ketiga yang dihimpun bank). Dalam penelitiannya Kholiq dan Rahmawati menyimpulkan bahwa pemberlakuan restrukturisasi kredit dimasa pandemi COVID-19 berpengaruh terhadap LDR/FDR (Kholiq \& Rahmawati, 2020). Sehingga dapat ditarik hipotesis beda setelah penerapan kebijakan restrukturisasi kredit di masa pandemi COVID-19 pada LDR/FDR sebagai berikut:

$\mathrm{Ho}_{4}$ : Tidak ada perbedaan rata-rata rasio LDR/FDR sebelum dan sesudah penerapan kebijakan restrukturisasi kredit di masa pandemi COVID-19

$\mathrm{Ha}_{4}$ : Ada perbedaan rata-rata rasio LDR/FDR sebelum dan sesudah penerapan kebijakan restrukturisasi kredit di masa pandemi COVID-19

\section{METODOLOGI PENELITIAN}

Penelitian ini adalah penelitian kuantitatif dengan pendekatan deskriptif. Data dalam penelitian ini menggunakan data sekunder, yaitu laporan keuangan tahunan bank terdaftar di OJK yang dipublikasikan oleh bank bersangkutan melalui laman elektronik (web site) resmi mereka. Data yang diambil adalah laporan keuangan tahun 2019 dan laporan keuangan tahun 2020. Pemilihan sample menggunakan metode purposive sampling, dengan kriteria bank telah beroperasi selama lima tahun atau lebih, menerbitkan laporan keuangan tahunan tahun 2020, tidak sebagai Bank dalam Pengawasan Khusus. Penelitian ini menggunakan Uji Wilcoxon untuk mengukur seberapa besar perbedaan kinerja keuangan perbankan di Indonesia, sebelum dan sesudah penerapan kebijakan restrukturisasi kredit di masa pandemi COVID-19. Pengolahan data pada penelitian ini menggunakan IBM SPSS versi 28. Variabel-variabel pada penelitian ini, yang digunakan yaitu:

1. Data sebelum penerapan kebijakan restrukturisasi kredit di masa pandemi COVID-19 yaitu sebelum diumumkannya pemberlakuan POJK No. 11 tahun 2020 meliputi data Laporan Keuangan Berupa NPL/NPF (Non Performing Loan/Financing), LDR/FDR (Loan/Financing to Deposit Ratio), ROA (Return on Assets), dan CAR (Capital Adequacy Ratio). Pada penelitian ini, data yang diambil sebelum pengumuman yaitu laporan keuangan tahun 2019 sebanyak 108.

2. Data sesudah penerapan kebijakan restrukturisasi kredit di masa pandemi COVID-19 yaitu setelah diumumkannya pemberlakuan Peraturan Otoritas Jasa Keuangan Republik Indonesia Nomor 11/POJK.03/2020 tentang Stimulus Perekonomian Nasional Sebagai Kebijakan Countercyclical Dampak Penyebaran COVID 19 meliputi data Laporan Keuangan Berupa NPL/NPF (Non Performing Loan/Financing), LDR/FDR (Loan/Financing to Deposit Ratio), ROA (Return on Assets), dan CAR (Capital 
Adequacy Ratio). Pada penelitian ini, data yang diambil setelah pengumuman yaitu laporan keuangan tahun 2020 sebanyak 108.

3. Penerapan kebijakan restrukturisasi kredit di masa pandemi COVID-19 pada saat pengumuman pemberlakuan Peraturan Otoritas Jasa Keuangan Republik Indonesia Nomor 11/POJK.03/2020 tentang Stimulus Perekonomian Nasional Sebagai Kebijakan Countercyclical Dampak Penyebaran COVID 19 pada 13 Maret 2020 dan berlaku sejak diundangkan pada 16 Maret 2020 sampai dengan 31 Maret 2021.

\section{HASIL DAN PEMBAHASAN}

\section{Uji Normalitas}

\begin{tabular}{|l|c|c|c|c|c|c}
\multicolumn{7}{c}{ Tests of Normality } \\
& \multicolumn{2}{c}{ Kolmogorov-Smirnov } & & \multicolumn{2}{c}{ Shapiro-Wilk } & \\
& Statistic & df & Sig. & Statistic & df & Sig. \\
\hline Rasio NPL 2019 & .117 & 108 & $<, 001$ & .931 & 108 & $<, 001$ \\
\hline Rasio NPL 2020 & .156 & 108 & $<, 001$ & .895 & 108 & $<, 001$ \\
\hline Rasio LDR 2019 & .334 & 108 & $<, 001$ & .311 & 108 & $<, 001$ \\
\hline Rasio LDR 2020 & .309 & 108 & $<, 001$ & .314 & 108 & $<, 001$ \\
\hline Rasio ROA 2019 & .218 & 108 & $<, 001$ & .701 & 108 & $<, 001$ \\
\hline Rasio ROA 2020 & .242 & 108 & $<, 001$ & .724 & 108 & $<, 001$ \\
\hline Rasio CAR 2019 & .273 & 108 & $<, 001$ & .476 & 108 & $<, 001$ \\
\hline Rasio CAR 2020 & .371 & 108 & $<, 001$ & .180 & 108 & $<, 001$ \\
\hline a. Lilliefors Significance Correction & & & & & \\
\hline
\end{tabular}

Dasar Pengambilan Keputusan Uji Kolmogorov-Sminov:

a. Jika nilai sig.>0.05, Maka distribusi data adalah normal

b. Jika nilai sig. $<0.05$, Maka distribusi data adalah tidak normal

1. Diketahui nilai sig. pada variable Rasio NPL/NPF 2019 yaitu sebesar $0,001<0,05$, maka distribusi data tidak normal

2. Diketahui nilai sig. pada variable Rasio NPL/NPF 2020 yaitu sebesar $0,001<0,05$, maka distribusi data tidak normal

3. Diketahui nilai sig. pada variable Rasio LDR/FDR 2019 yaitu sebesar 0,001<0,05, maka distribusi data tidak normal

4. Diketahui nilai sig. pada variable Rasio LDR/FDR 2020 yaitu sebesar $0,001<0,05$, maka distribusi data tidak normal

5. Diketahui nilai sig. pada variable Rasio ROA 2019 yaitu sebesar $0,001<0,05$, maka distribusi data tidak normal

6. Diketahui nilai sig. pada variable Rasio ROA 2020 yaitu sebesar $0,001<0,05$, maka distribusi data tidak normal

7. Diketahui nilai sig. pada variable Rasio CAR 2019 yaitu sebesar $0,001<0,05$, maka distribusi data tidak normal

8. Diketahui nilai sig. pada variable Rasio CAR 2019 yaitu sebesar $0,001<0,05$, maka distribusi data tidak normal

Berdasar hasil uji Kolmogorov-Sminov diatas dapat disimpulkan bahwa dari sample Rasio NPL/NPF tahun 2019, Rasio NPL/NPF tahun 2020, Rasio LDR/FDR tahun 2019, Rasio LDR/FDR tahun 2020, Rasio ROA tahun 2019, Rasio ROA tahun 2020, dan Rasio CAR tahun 2019, Rasio CAR tahun 2020 distribusi data tidak normal. Oleh karena itu uji beda sample berpasangan dilakukan menggunakan uji Non Parametrik Wilcoxon.

\section{RAAR}

Vol.2 No.1 


\section{Uji Wilcoxon}

1. Pengujian Hipotesis 1

$\mathrm{Ho}_{1}$ : Tidak ada perbedaan rata-rata rasio NPL/NPF sebelum dan sesudah penerapan kebijakan restrukturisasi kredit di masa pandemi COVID-19

$\mathrm{Ha}_{1}$ : Ada perbedaan rata-rata rasio NPL/NPF sebelum dan sesudah penerapan kebijakan restrukturisasi kredit di masa pandemi COVID-19

\begin{tabular}{|c|c|c|c|c|}
\hline \multicolumn{5}{|c|}{ Test Statistics $^{\mathrm{a}}$} \\
\hline & $\begin{array}{c}\text { Rasio NPL } \\
2020 \text { - Rasio } \\
\text { NPL 2019 }\end{array}$ & $\begin{array}{c}\text { Rasio LDR } \\
2020 \text { - Rasio } \\
\text { LDR 2019 }\end{array}$ & $\begin{array}{c}\text { Rasio ROA } \\
2020 \text { - Rasio } \\
\text { ROA 2019 }\end{array}$ & $\begin{array}{c}\text { Rasio CAR } \\
2020 \text { - Rasio } \\
\text { CAR } 2019\end{array}$ \\
\hline$z$ & $-1.727^{b}$ & $-3.842^{\mathrm{b}}$ & $-2.507^{b}$ & $-5.021^{\circ}$ \\
\hline Asymp. Sig. (2-tailed) & .084 & $<, 001$ & .012 & $<, 001$ \\
\hline
\end{tabular}

Dari table Test Statistics diatas didapat nilai probabilitas (Asymp.sig. $(2$ tiled $))=0.084$

Keputusan hasil:

Dari out put dapat dilihat bahwa nilai probabilitas (Asymp.sig) adalah 0,084> 0,05, maka $\mathrm{Ho}_{1}$ diterima, berarti bahwa tidak ada perbedaan rata-rata yang signifikan rasio NPL/NPF sebelum dan sesudah penerapan kebijakan restrukturisasi kredit di masa pandemi COVID-19

2. Pengujian Hipotesis 2

$\mathrm{Ho}_{2}$ : Tidak ada perbedaan rata-rata rasio CAR sebelum dan sesudah penerapan kebijakan restrukturisasi kredit di masa pandemi COVID-19

$\mathrm{Ha}_{2}$ : Ada perbedaan rata-rata rasio CAR sebelum dan sesudah penerapan kebijakan restrukturisasi kredit di masa pandemi COVID-19

Dari table Test Statistics diatas didapat nilai probabilitas (Asymp.sig. $(2$ tiled $)$ ) $=0.001$

Keputusan hasil:

Dari out put dapat dilihat bahwa nilai probabilitas (Asymp.sig) adalah $0,001<0,05$, maka $\mathrm{Ho}_{2}$ ditolak, berarti bahwa ada perbedaan rata-rata yang signifikan rasio CAR sebelum dan sesudah penerapan kebijakan restrukturisasi kredit di masa pandemi COVID-19

\section{Pengujian Hipotesis 3}

$\mathrm{Ho}_{3}$ : Tidak ada perbedaan rata-rata rasio ROA sebelum dan sesudah penerapan kebijakan restrukturisasi kredit di masa pandemi COVID-19

$\mathrm{Ha}_{3}$ : Ada perbedaan rata-rata rasio ROA sebelum dan sesudah penerapan kebijakan restrukturisasi kredit di masa pandemi COVID-19

Dari table Test Statistics diatas didapat nilai probabilitas (Asymp.sig. $(2$ tiled $))=0.012$ Keputusan hasil:

Dari out put dapat dilihat bahwa nilai probabilitas (Asymp.sig) adalah 0,012<0,05, maka $\mathrm{Ho}_{3}$ ditolak, berarti bahwa ada perbedaan rata-rata yang signifikan rasio ROA sebelum dan sesudah penerapan kebijakan restrukturisasi kredit di masa pandemi COVID-19

4. Pengujian Hipotesis 4

Ho4: Tidak ada perbedaan rata-rata rasio LDR/FDR sebelum dan sesudah penerapan kebijakan restrukturisasi kredit di masa pandemi COVID-19 
$\mathrm{Ha}_{4}$ : Ada perbedaan rata-rata rasio LDR/FDR sebelum dan sesudah penerapan kebijakan restrukturisasi kredit di masa pandemi COVID-19

Dari table Test Statistics diatas didapat nilai probabilitas (Asymp.sig. $(2$ tiled $))=0.001$

Keputusan hasil:

Dari out put dapat dilihat bahwa nilai probabilitas (Asymp.sig) adalah 0,001<0,05, maka $\mathrm{Ho}_{4}$ ditolak, berarti bahwa ada perbedaan rata-rata yang signifikan rasio LDR/FDR sebelum dan sesudah penerapan kebijakan restrukturisasi kredit di masa pandemi COVID-19

\section{Pembahasan}

1. Didapat dari table Descriptive Statistics, nilai rata-rata rasio NPL/F 2019 sebesar 1,7101\% lebih besar dari nilai rata-rata rasio NPL/F 2020 sebesar 1,5865\% (peringkat sangat sehat), sehingga ada penurunan rasio NPL/F sebesar $0,1236 \%$ (peringkat sangat sehat). Namun penurunan ini berdasar uji Wilcoxon ternyata secara rata-rata tidak ada perbedaan yang signifikan pada rasio NPL/F sebelum dan sesudah penerapan kebijakan restrukturisasi kredit di masa pandemi COVID-19.

Sedangkan apabila diperhatikan berdasar tabel statistik deskriptif diatas, dapat dilihat bahwa nilai tertinggi NPL/F pada tahun 2019 adalah 4,96\% (peringkat sehat) mendekati batas peringkat cukup baik, sedangkan nilai tertinggi pada tahun 2020 adalah 5,64\% (peringkat cukup sehat) melampaui batas peringkat cukup baik. Ini berarti ada bank yang termasuk dalam kondisi buruk, walau secara rata-rata penerapan kebijakan restrukturisasi kredit di masa pandemi COVID-19 dapat dikatakan berhasil menjaga nilai NPL/F pada peringkat sehat.

\begin{tabular}{|l|r|r|r|r|r}
\multicolumn{7}{c}{ Descriptive Statistics } \\
& N & \multicolumn{1}{c|}{ Mean } & Std. Deviation & Minimum & Maximum \\
\hline Rasio NPL 2019 & 108 & 1.7101 & 1.49644 & -3.30 & 4.96 \\
\hline Rasio LDR 2019 & 108 & 105.1581 & 92.03311 & 23.02 & 971.60 \\
\hline Rasio ROA 2019 & 108 & 1.3687 & 2.89740 & -15.89 & 14.06 \\
\hline Rasio CAR 2019 & 108 & 28.0586 & 23.91534 & 9.01 & 201.00 \\
\hline Rasio NPL 2020 & 108 & 1.5865 & 1.43298 & .00 & 5.64 \\
\hline Rasio LDR 2020 & 108 & 98.4951 & 94.02486 & .00 & 996.74 \\
\hline Rasio ROA 2020 & 108 & 1.1048 & 2.69230 & -14.11 & 11.25 \\
\hline Rasio CAR 2020 & 108 & 36.6434 & 77.75262 & 10.95 & 820.90 \\
\hline
\end{tabular}

2. Didapat dari table Descriptive Statistics, nilai rata-rata rasio CAR 2019 sebesar 28,0586\% lebih kecil dari nilai rata-rata rasio CAR 2020 sebesar 36,6434\%, sehingga ada peningkatan rasio CAR di tahun 2020 sebesar 8,5848\%. Peningkatan CAR ini menurut uji Wilcoxon memiliki makna bahwa ada perbedaan rata-rata yang signifikan pada rasio CAR sebelum dan sesudah penerapan kebijakan restrukturisasi kredit di masa pandemi COVID-19. Dan apabila diperhatikan dengan seksama, berdasar tabel statistik deskriptif terlihat bahwa batas minimum CAR pada tahun 2019 yaitu pada angka 9,01\% masih berada diatas CAR minimal yang diizinkan OJK, dan meningkat pada tahun 2020 sebesar 10,95\%. Ini menggambarkan bahwa kebijakan restrukturisasi kredit berhasil mempertahankan kondisi ideal permodalan perbankan, yang cenderung meningkat diatas batas CAR Minimal yang diperkenankan OJK yaitu sebesar $8 \%$.

3. Didapat dari table Descriptive Statistics, nilai rata-rata rasio ROA 2019 sebesar 1,3687 Vol.2 No.1 (peringkat sehat) lebih besar dari nilai rata-rata rasio ROA 2020 sebesar 1,1048 
(peringkat cukup sehat), sehingga ada penurunan rasio ROA. Penurunan ini berdasar uji Wilcoxon membuktikan bahwa kemampuan bank dalam menghasilkan laba mengalami penurunan yang signifikan. Hal ini merupakan efek logis dari kebijakan restrukturisasi kredit, dimana kebijakan ini mengakibatkan tenor kredit perbankan menjadi lebih panjang. Selain itu, perlu diwaspadai bahwa berdasar tabel Descriptive Statistics diatas baik pada tahun 2019 dan tahun 2020 terdapat nilai minimal ROA yang berada pada level negative, hal ini menunjukkan bahwa ada bank yang dalam kondisi tidak sehat.

4. Didapat dari table Descriptive Statistics, nilai rata-rata rasio LDR/FDR 2019 sebesar 105,1581 lebih besar dari nilai rata-rata rasio LDR/FDR 2020 sebesar 98,4951, sehingga ada penguatan rasio LDR/FDR sebesar 6,663\%. Penguatan ini berdasar uji Wilcoxon dianggap signifikan, yaitu dari peringkat kurang sehat di tahun 2019 menjadi peringkat cukup sehat di tahun 2020. Namun yang perlu diperhatikan berdasar informasi tabg disajikan pada table Descriptive Statistics diatas, bahwa masih terdapat bank yang memiliki rasio LDR/FDR pada peringkat tidak sehat (>120\%), baik di tahun 2019 maupun yahun 2020 .

\section{SIMPULAN DAN SARAN}

\section{Implikasi Teoritis}

Implikasi kebijakan restrukturisasi kredit secara teoritis dalam penelitian ini yaitu sebagai berikut:

1. Hasil penelitian menunjukkan bahwa tidak ada perbedaan yang signifikan antara Rasio Non Performing Loan/Finance (NPL/F) sebelum dan sesudah penerapan kebijakan restrukturisasi kredit di masa pandemi COVID-19.

2. Hasil penelitian menunjukkan bahwa ada perbedaan yang signifikan antara Capital Adeqaucy Ratio (CAR) sebelum dan sesudah penerapan kebijakan restrukturisasi kredit di masa pandemi COVID-19.

3. Hasil penelitian menunjukkan bahwa ada perbedaan yang signifikan antara ROA sebelum dan sesudah penerapan kebijakan restrukturisasi kredit di masa pandemi COVID-19.

4. Hasil penelitian menunjukkan bahwa ada perbedaan yang signifikan antara Finance/Loan to Deposit Ratio (F/LDR) sebelum dan sesudah penerapan kebijakan restrukturisasi kredit di masa pandemi COVID-19.

\section{Implikasi Manajerial}

Penelitian ini, memberikan gambaran bagi kita bahwa teori terkait tekanan krisi ekonomi dapat dibuktikan secara empiris. Penelitian ini juga membuktikan bahwa keadaan fiskal dan moneter Indonesia dapat di arahkan oleh pemerintah melalui kebijakan yang tepat. Bagi perbankan yang melaksanakan kebijakan restrukturisasi kredit di masa pandemi COVID-19, penelitian ini membuktikan bahwa langkah penyelamatan para debitur pada dasarnya adalah usaha untuk menjaga keberlangsungan hidup mereka. Serta untuk menjaga kemungkinan terjadinya krisis sistemik yang disebabkan wanpretasi debitur, yang pada gilirannya akan menimbulkan gagal bayar terhadap kewajiban mereka.

RAAR Berdasar hasil penelitian ini, pengelola bank dituntut untuk memiliki manajemen krisis Vol.2 No.1 yang mumpuni, serta lebih peka dalam memiliki sense of crisis. Sehingga jika kemungkinan terburuk terjadi hal yang serupa, pengelola bank dapat lebih siap penanganannya. Dan memiliki strategi maupun langkah-langkah yang dapat menjaga 
kondisi keuangan perbankan tetap stabil dan tidak mengalami goncangan. Tentu dengan pertimbangan bahwa kepentingan nasional dan masyarakat harus diutamakan.

\section{Keterbatasan Penelitian}

Dalam penyusunan penelitian ini terdapat beberapa keterbatasan, antara lain:

1. Periode yang digunakan yaitu satu tahun sebelum penerapan kebijakan restrukturisasi kredit di masa pandemi COVID-19 dan satu tahun setelah penerapan kebijakan restrukturisasi kredit di masa pandemi COVID-19, yaitu tahun 2019 dan tahun 2020.

2. Penelitian hanya memilih kinerja keuangan sektor perbankan, padahal pada saat krisis dimasa pandemi seluruh sektor perekonomian lainnya juga terpengaruh, maka sebenarnya sektor perekonomian lainnya juga patut dikaji.

3. Penelitian ini hanya menggunakan rasio NPL/NPF, CAR, ROA, LDR/FDR padahal masih banyak lagi rasio lainnya yang bisa melengkapi metode (Risk-based Bank Rating/RBBR).

\section{Agenda Penelitian Mendatang}

Dalam penyusunan penelitian ini terdapat beberapa agenda penelitian mendatang, antara lain:

1. Periode yang digunakan dapat lebih jauh lagi seperti dua sampai tiga tahun sebelum dan sesudah penerapan kebijakan restrukturisasi kredit di masa pandemi COVID-19, dimana pada tahun tersebut kondisi kinerja keuangan perbankan kemungkinan sudah stabil.

2. Penelitian mendatang sebaiknya dapat mengkaji kinerja keuangan di sektor lainnya selain perbankan, sehingga wawasan kinerja keuangan sebelum dan sesudah penerapan kebijakan restrukturisasi kredit di masa pandemi COVID-19 lebih luas dan tidak hanya di sektor perbankan, namun di sektor perekonomian lainnya. Antara lain dari sisi perusahaan penerima manfaat restrukturisasi yaitu para UMKM.

3. Penelitian selanjutnya sebaiknya juga memperluas penggunaan rasio keuangan, sehingga dapat melengkapi dan menambah pengetahuan dari penelitian sebelumnya.

\section{REFERENSI}

Adhinugroho, B. (2021). Dampak Peningkatan Restrukturisasi Utang Akibat Covid-19 Terhadap Profitabilitas Perusahaan Perbankan. The 2nd Seminar Nasional ADPI Mengabdi Untuk Negeri Pengabdian Masyarakat Di Era New Normal, 2(2), 19-23.

Aiyar, S., Bergthaler, W., Garrido, J., Ilyina, A., Jobst, A., Kang, K., Kovtun, D., Liu, Y., Monaghan, D., \& Moretti, M. (2015). A Strategy for Resolving Europe's Problem Loans. Staff Discussion Notes, 15(19), 1. https://doi.org/10.5089/9781513591278.006

Bank Indonesia. (2011). Peraturan Bank Indonesia No.13/1/PBI/2011 Tentang Penilaian Tingkat Kesehatan Bank. Peraturan Bank Indonesia, 1-31.

Davis, E. (2003). Towards a typology for systemic financial instability. Economics and Finance Working Papers, Brunel University, 2, 1-23. http://bura.brunel.ac.uk/handle/2438/916

Firdaus, Rachmat; Ariyanti, M. (2003). Manajemen perkreditan bank umum: teori, masalah, kebijakan dan aplikasinya lengkap dengan analsiis kredit. Alfabeta.

Hariyani, I. (2010). Restrukturisasi dan Penghapusan Kredit Macet. Elex Media Komputindo. 
Junaedi, D., \& Salistia, F. (2020). Dampak Pandemi COVID-19 Terhadap Pertumbuhan Ekonomi Negara-Negara Terdampak. In Simposium Nasional Keuangan Negara (pp. 995-1115).

Kalemli-Özcan, S., Laeven, L., \& Moreno, D. (2019). Debt Overhang, Rollover Risk, and Corporate Investment: Evidence from the European Crisis. Ssrn. https://doi.org/10.3386/w24555

Kasmir. (2018). Analisis laporan keuangan. Rajawali Pers.

Kholiq, A., \& Rahmawati, R. (2020). Dampak Implementasi Restrukturisasi Pembiayaan terhadap Likuiditas Bank Syariah pada Situasi Pandemi Covid-19. El-Barka: Journal of Islamic Economics and Business, 3(2), 282-316. https://doi.org/10.21154/elbarka.v3i2.2472

Otoritas Jasa Keuangan. (2017). POJK Nomor 04/SEOJK.03/2016 Tentang Penilaian Tingkat Kesehatan Bank Umum. Peraturan Otoritas Jasa Keuangan, 33. https://www.ojk.go.id/id/kanal/perbankan/regulasi/peraturan-ojk/Pages/pojk-tentangpenilaian-tingkat-kesehatan-bank-umum.aspx

Otoritas Jasa Keuangan. (2020). Salinan Peraturan Otoritas Jasa Keuangan Republik Indonesia Nomor 11/Pojk.03/2020. 2019, 1-23. https://peraturan.bpk.go.id/Home/Download/126415/Peraturan OJK Nomor 11 Tahun 2020.pdf

Otoritas Jasa Keuangan. (2021). Statistik Perbankan Indonesia. https://www.ojk.go.id/id/kanal/perbankan/data-dan-statistik/statistik-perbankanindonesia/Pages/Statistik-Perbankan-Indonesia---Januari-2021.aspx

Pemerintah Republik Indonesia. (1998). Undang Undang Nomor 10 Tahun 1998 tentang $\begin{array}{lllllll}\text { Perubahan atas UU Nomor } 7 & \text { Tahun } & \end{array}$ http://www.komnasham.go.id/sites/default/files/dokumen/UU NO 39 TAHUN 1999 HAM_0.pdf

Sihotang, B., \& Sari, E. K. (2019). Restrukturisasi Sebagai Penyelamatan Kredit Bermasalah Pada Bank. Prosiding Seminar Nasional Pakar Ke 2 Tahun 2019, 2(10), $1-6$.

Veithzal, Rivai, A. P., \& Idroes, V. dan F. N. (2007). BANK and Financial Institution Management. Rajawali Press. 